UNDERGRADUATE RESEARCH IN NATURAL AND CLINICAL SCIENCE AND TECHNOLOGY (URNCST) JOURNAL Read more URNCST Journal articles and submit your own today at: https://www.urncst.com

\title{
siRNA-Mediated Silencing of Antifungal Resistance Genes: A Research Protocol
}

Will D. Jeong, HBSc Student [1], Sean D. Jeong, HBSc Student [1], Katelyn R. Wang, HBSc Student [1], Alston Lo, HBSc Student [1]

[1] University of Toronto St. George, Toronto, Ontario, Canada M5S

*Corresponding Author: seand.jeong@ mail.utoronto.ca

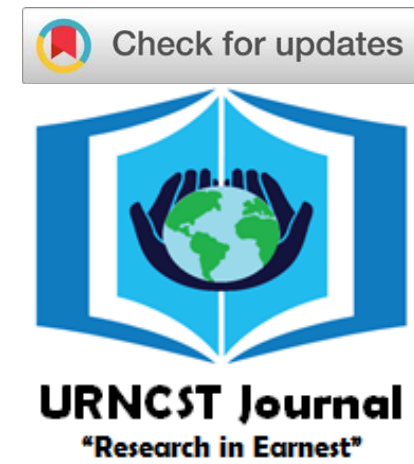

\begin{abstract}
Introduction: Antifungal resistance (AFR) is an underrepresented issue that threatens both global health and food security. A common feature of many pathogenic fungi is their ability to produce RNA-induced silencing complexes (RISC) to protect against mycoviruses, thereby silencing the expression of targeted genes. Herein, we aim to create a genetically-modified mycovirus which can silence AFR genes specific to tebuconazole by leveraging the RISC silencing mechanism against the fungi's native genes.

Methods: To investigate the possible effects of mycoviruses on AFR, Fusarium graminearum (Fg) cultures will be infected with modified Fusarium graminearum deltaflexivirus 1 (mFgDFV1), each of which contain a $600 \mathrm{nt} \mathrm{Fg} \mathrm{ATP-binding} \mathrm{cassette}$ 3 (FgABC3) segment (an azole resistance gene). $\mathrm{mFgDFV} 1$ will be produced from Saccharomyces cerevisiae via an episomal plasmid and subsequently purified using an aqueous two-phase system. Thereafter, a Western and Northern blot will be employed to confirm successful mFgDFV1 synthesis. The efficacy of mFgDFV1 on repressing AFR will be evaluated by comparing the minimum inhibitory concentration $\left(\mathrm{MIC}_{50}\right.$ and $\mathrm{MIC}_{90}$ ) of tebuconazole for $\mathrm{Fg}$ groups treated with $\mathrm{mFgDFV} 1$, wild-type FgDFV1, or no virus via protoplast fusion.

Results: Upon completion of the experiments above, 3 sets of $\mathrm{MIC}_{50}$ and $\mathrm{MIC}_{90}$ values will be obtained. Each set will correspond to either mFgDFV1 treatment, wild-type FgDFV1 control, or water control. It is expected that Fg treated with mFgDFV1 will induce RISC, silencing $\mathrm{FgABC} 3$ and thus lowering $\mathrm{MIC}_{50}$ and $\mathrm{MIC}_{90}$ relative to both controls.

Discussion: If effective, this approach to addressing AFR could be advantageous given the utility of RISC in fungi (e.g., if fungi downregulate the RISC response, they would become more susceptible to other viruses). Moreover, this method could be translated to a variety of other genetic and fungal targets if desired.

Conclusion: This article presents a method to effectively overcome antifungal resistance by exploiting the fungal short interfering RNA defense mechanism. Should this experiment be successful, this modified Fg virus treatment could potentially stop multidrug-resistant $\mathrm{Fg}$ infestations, although further experimentation is required. Future studies could study the effectiveness of other antifungal resistant fungi and/or examine the biosafety and ecological footprint of this method.
\end{abstract}

Keywords: mycovirus; siRNA; RISC; antifungal resistance; Fusarium graminearum; Fusarium graminearum deltaflexivirus 1

\section{Introduction}

Fungal infections pose a serious threat to global health and food security, being responsible for over 1.6 million deaths, 300 million hospitalizations, and the destruction of more than 125 million tonnes of crops every year [1-3]. Furthermore, with the proliferation of multidrug-resistant fungi outpacing the rate of antifungal drug development, there is a growing need for new methods of fungal control [1]. In part, the delay in antifungal drug development arises from the unique nature of fungal pathogens. Unlike prokaryotic pathogens, eukaryotic fungi share many biochemical similarities to their eukaryotic hosts; thus, developing antifungals that minimally harm the host is challenging [4].
Fusarium graminearum $(\mathrm{Fg})$ is a particularly destructive phytopathogen responsible for Fusarium head blight (FHB), a disease that hinders the quality and yield of cereal crops [5]. While azole fungicides have been the traditional solution to FHB, their efficacy is rapidly declining due to the emergence of azole-resistant strains [6]. One possible solution to this growing problem is phage therapy, whereby fungi are infected with positive-sense single-stranded RNA (+ssRNA) mycoviruses such as Fusarium graminearum deltaflexivirus 1 (FgDFV1), to induce hypovirulence [7]. However, hypovirulence is rarely observed due to Fg's powerful antiviral defense mechanisms which suppress viral gene expression, one particularly notable mechanism being RNA-induced silencing complex (RISC) silencing [8]. RISC silencing is initiated during viral replication, after +ssRNA 
UNDERGRADUATE RESEARCH IN NATURAL AND CLINICAL SCIENCE AND TECHNOLOGY (URNCST) JOURNAL Read more URNCST Journal articles and submit your own today at: https://www.urncst.com

mycoviruses form double-stranded RNA (dsRNA) intermediates. In response to these foreign intermediates, the fungal host cleaves the dsRNA into many 21-24 nt short interfering RNA (siRNA) duplexes via Dicer-like protein 2
[7,9]. Subsequently, RISC and Argonaute bind to an siRNA duplex, discarding one strand and using the other to degrade complementary messenger RNA (mRNA) [7].

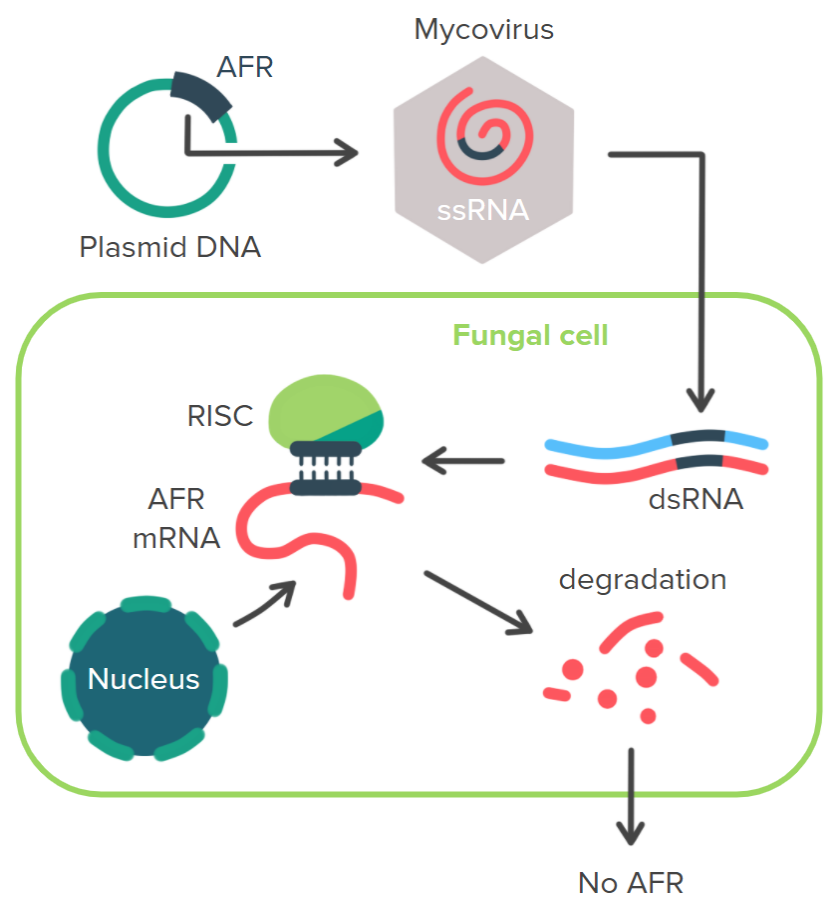

Figure 1. A graphical summary of our hypothesized pathway of siRNA-mediated antifungal resistance (AFR) gene downregulation. Figure 1 was made using Paint Tool SAI $[9,10]$.

As RISC cannot distinguish between viral and fungal mRNA, we hypothesize that infecting fungi with AFR insert mycoviruses will induce RISCs complementary to AFR genes, downregulating their expression (Figure 1) [11]. Therefore, we propose a study investigating the use of genetically-modified mycoviruses to silence AFR gene expression [9]. Fg and FgDFV1 will be used to model this process, and if successful, similar systems could be applied to other fungi-mycovirus pairs.

\title{
Methods
}

$\underline{\text { AFR Sequence Selection }}$

\begin{abstract}
tacggcattagccacaccatcaacacccaagtcggcgacaactacatccgaggtgtatctggaggtgagagaaagcgagtcaccatcgecgaagcgacgctctcca acgccccettccaatgttgggacaactcaacccgtggtttggattcagccaacgccatcgagttctgcaagacgttgcgtttgcaatccgagctctttggacagacttgc gctgtctcgatctaccaagcacccagacagcgtacgatctcttcgacaaggccetcgtcatctacgaaggacgtcagatcttctttggtcccgccgacgaagcaaag gcctactttatcaacctcggcttcgaatgtcccgaccgtcaaacaacgectgatttccttacgtccatgactgegecatctgaacgcgttgtccgtcetggctgggagaa caaggtcccacgcacaccegatgagttccacgecegttggaaggagagccagcagtaccagattgtccgegecgagattgagagctacaagagcctctacccct caacggttccagcgccgacgccttccgcgagaacaagcattccgcacaggcaaagggccaa
\end{abstract}

Figure 2A. The $600 \mathrm{nt}$ target sequence selected from Fg ATP-binding cassette 3 (FgABC3) [12-14].

\section{YGISHTINTQVGDNYIRGVSGGERKRVTIAEATLSNAPFQCWDNSTRGLDSANAIEFCKTLRLQSELFGQT CAVSIYQAPQTAYDLFDKALVIYEGRQIFFGPADEAKAYFINLGFECPDRQTTPDFLTSMTAPSERVVRPG WENKVPRTPDEFHARWKESQQYQIVRAEIESYKSLYPLNGSSADAFRENKHSAQAKGQ}

Figure 2B. The 200 amino acid target sequence selected from FgABC3 [12-14]. 
The AFR gene FgABC3 will be targeted due to its role in encoding ATP-binding cassette (ABC) proteins that aid in resisting azole fungicides, such as tebuconazole [6]. Specifically, the target sequence will be $600 \mathrm{nt}$ in length (amino acids 289-488). This particular region and range was chosen as it corresponds to a conserved segment of the $\mathrm{ABC}$ transporter 1 domain (including the AAA+ ATPase domain and the family $\mathrm{G}$ domain), and can produce up to $25-28$ siRNA (given each siRNA is $\sim 21-24$ nt in length) per viral genome (Figure 2A, Figure 2B) [7,15].

\section{Modified FgDFV1 (mFgDFV1) Synthesis}

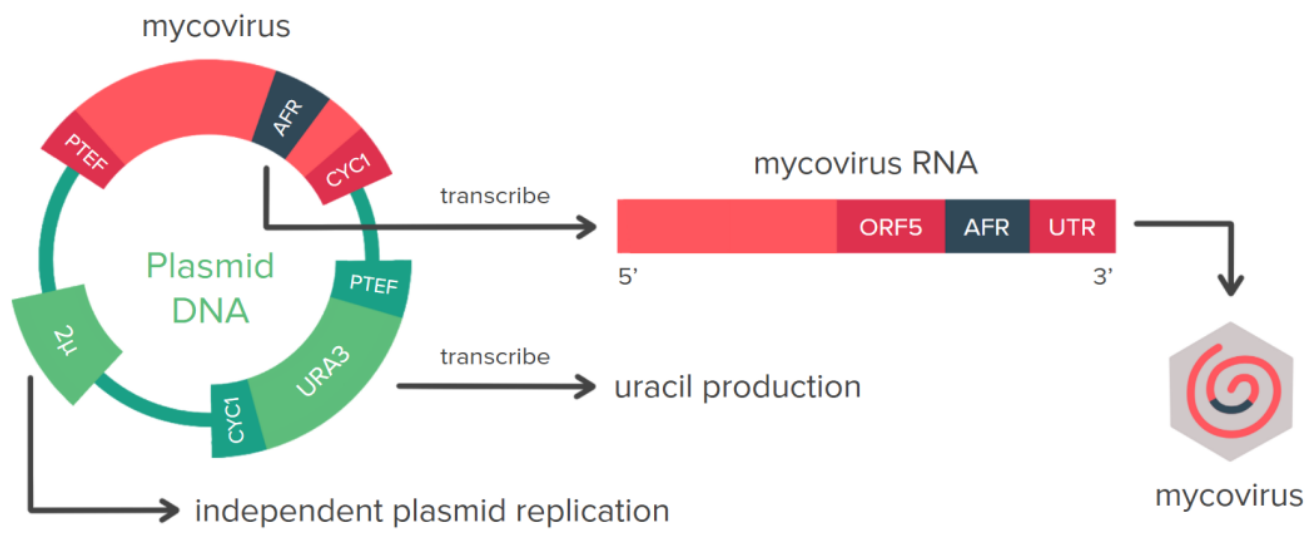

Figure 3: S. cerevisiae episomal plasmid and the transcribed mFgDFV1 sequence. Figure 3 was made using Paint Tool SAI $[10,16]$.

\section{Saccharomyces cerevisiae Transformation}

An episomal Saccharomyces cerevisiae plasmid (Figure 3) encoding FgDFV1, a segment of the target AFR gene, and an auxotrophic URA3 selection marker will be constructed using GeneArt ${ }^{\mathrm{TM}}$ gene synthesis (Thermo Fisher Scientific) [17]. The AFR segment will be inserted between FgDFV1's terminal open reading frame (ORF) and 3' untranslated region (UTR), thereby preventing interference with viral protein synthesis and 3' UTR-mediated RNA replication [18]. Transcription of this modified sequence will be regulated with a $\mathrm{P}_{\mathrm{TEF} 1}$ yeast promoter and $\mathrm{CYC} 1$ terminator sequence [19]. A separate $\mathrm{P}_{\mathrm{TEF} 1}$ will be present to promote URA3 expression. The $S$. cerevisiae DBY947 (MATa, ade2101, ura3-5) strain will be subsequently transformed via a YEAST1 transformation kit, and then cultured in a uracil deficient Y1501 medium to select for the desired strain.20 To facilitate viral growth, this culture will be incubated at $30^{\circ} \mathrm{C}$ for 48 hours.

\section{Mutant Mycovirus Purification}

Isolating mycoviral particles from the yeast will occur in two stages. First, a CellLytic ${ }^{\mathrm{TM}}$ Kit will be employed to lyse the transformed yeast, releasing mFgDFV1 (SigmaAldrich) [21]. Next, to purify mFgDFV1, a two-phase aqueous system using polyethylene glycol and salt will be used, as outlined by Zhang et al [22].

\section{Mutant Mycovirus Confirmation}

To confirm mFgDFV1 synthesis and isolation, a Western blot using FgDFV1 primary antibodies (prepared as outlined in Mahmood and Yang) will be employed to establish the presence of a functional viral capsid, while a Northern blot utilizing a probe complementary to the AFR insert will demonstrate if AFR integration was successful $[23,24]$. In regard to the Northern blot, the mutant mycovirus band is also expected to appear 600 base pairs longer than the control mycovirus band due to the insertion of the AFR sequence.

Viral Acquisition and Efficacy

\section{Fungal Cultivation}

Three experimental groups of the tebuconazole-resistant Fg strain PH1 will be cultivated in separate potato dextrose agarose (PDA) plates with RPMI medium 1640 (Thermo Fisher Scientific) [25]. These colonies will be incubated at $25 \pm 2^{\circ} \mathrm{C}$ for 5 days prior to treatment [6].

\section{$m F g D F V 1$ Delivery}

Each plate will be treated with either a mycovirus or control via protoplast fusion as outlined by Lee et al [26]. Specifically, PDA plate 1 will be the experimental group, infected by $\mathrm{mFgDFV} 1$. Plate 2 will serve as an active control, exposed to wild-type FgDFV1. Lastly, plate 3 will undergo protoplast induction without mycoviral delivery, acting as a negative control. Reverse transcription polymerase chain reaction (RT-PCR) using Fg RNA specific primers will be used on a small sample of each plate to confirm the presence of viral RNA and hence successful infection. Upon confirmation, the plates will undergo further incubation at room temperature for 48 hours to ensure RISC synthesis [27]. 
UNDERGRADUATE RESEARCH IN NATURAL AND CLINICAL SCIENCE AND TECHNOLOGY (URNCST) JOURNAL Read more URNCST Journal articles and submit your own today at: https://www.urncst.com

\section{Minimum Inhibitory Concentration $\left(M_{50}\right.$ and $\left.M I C_{90}\right)$ Determination}

To quantify mFgDFV1's effect on antifungal resistance, the minimum inhibitory concentration (MIC) test will be employed. First, six 96-well potato dextrose broth microtiter plates will be filled with $200 \mu \mathrm{L}$ of RPMI medium 1640 (Thermo Fisher Scientific) [25], yielding 48 rows of which 16 rows will be designated for each of the three experimental groups. Accordingly, twofold serial dilutions of tebuconazole will be prepared along each row of well plates $(256 \mathrm{~g} / \mathrm{L}$ to $0.25 \mathrm{~g} / \mathrm{L}$ and a $0 \mathrm{~g} / \mathrm{L}$ plate). This range was chosen to encompass the literature $\mathrm{Fg}$ tebuconazole $\mathrm{MIC}_{50}(32 \mathrm{~g} / \mathrm{L})$ and the $\mathrm{MIC}_{90}$, which is conventionally one dilution higher (64 $\mathrm{g} / \mathrm{L}$ ) than the $\mathrm{MIC}_{50}$ in the absence of $\mathrm{Fg}$ subpopulations
$[28,29]$. Equal amounts of Fg conidia suspensions from each PDA plate will then be introduced into their associated wells [30]. These plates will be incubated at $25 \pm 2^{\circ} \mathrm{C}$ for 7 days, after which the 16 MIC values for each group will be determined by inspection to complete corresponding $\mathrm{MIC}_{50}$ and $\mathrm{MIC}_{90}$ calculations [31].

\section{Results}

Altogether, $\mathrm{MIC}_{50}$ and $\mathrm{MIC}_{90}$ values for plate 1 (mFgDFV1), 2 (wild-type FgDFV1), and 3 (water) are anticipated at least 4 days after AFR sequence selection. Table 1 describes the range of possible results and the relative MIC values required to support this article's hypothesis.

Table 1. Range of possible $\mathrm{MIC}_{50}$ and $\mathrm{MIC}_{90}$ values for tebuconazole (g/L) for each treatment group; water, wild-type FgDFV1, and mFgDFV1.

\begin{tabular}{|l|l|l|l|}
\hline & Control \#1 (Water) & Control \#2 (WT FgDFV1) & Treatment (mFgDFV1) \\
\hline MIC $_{50}$ & $0-256 \mathrm{~g} / \mathrm{L}$ & $0-256 \mathrm{~g} / \mathrm{L}$ & $0-256 \mathrm{~g} / \mathrm{L}$ (Lowest) \\
\hline MIC $_{90}$ & $0-256 \mathrm{~g} / \mathrm{L}$ & $0-256 \mathrm{~g} / \mathrm{L}$ & $0-256 \mathrm{~g} / \mathrm{L}$ (Lowest) \\
\hline
\end{tabular}

\section{Discussion}

$\mathrm{MIC}_{50}$ and $\mathrm{MIC}_{90}$ values are associated with drug resistance: a lower $\mathrm{MIC}_{50}$ and $\mathrm{MIC}_{90}$ implies decreased resistance, whereas a higher $\mathrm{MIC}_{50}$ and $\mathrm{MIC}_{90}$ indicates increased resistance. Thus, one can assess the efficacy of mFgDFV1 treatment by comparing its MIC value against its controls (wild-type FgDFV1 and water). If mFgDFV1 $\mathrm{MIC}_{50}$ and $\mathrm{MIC}_{90}$ values are lower than both controls, mFgDFV1 treatment likely exploits RISC to effectively downregulate $\mathrm{AFR}$. If $\mathrm{mFgDFV}_{1} \mathrm{MIC}_{50}$ and $\mathrm{MIC}_{90}$ values are lower than that of the water control but comparable to the FgDFV1 control, treatment efficacy is seemingly attributable to the effects of viral infection alone. Lastly, if mFgDFV1 MIC 50 and $\mathrm{MIC}_{90}$ values are higher or comparable to both controls, the treatment is presumably not effective and alternative routes for disrupting AFR should be explored.

If our experimental results support our hypothesis, $\mathrm{mFgDFV} 1$ may prove useful in controlling multidrugresistant Fg infestations. This method presents several advantages. First, $\mathrm{mFgDFV} 1$ resistance is unlikely given the importance of siRNA silencing in fungi and the exploitation of the entire pathway as opposed to an individual protein [32]. Without siRNA, fungi are vulnerable to various sources of dangerous exogenous DNA such as viruses and transposons. Furthermore, siRNA have been implicated in a variety of fungal pathways, including endogenous gene regulation, heterochromatinization of centromeric regions, and stress adaptation amongst others [33]. Thus, trading off siRNA's defensive and general utility for mFgDFV1 resistance would not be expected. Additionally, we suspect that mutations capable of obstructing mFgDFV1 treatment are less probable than those that develop in response to conventional protein-target treatments. For instance, azoles typically target Cyp51A, an enzyme involved in the ergosterol biosynthetic pathway critical for the maintenance of fungal cell membranes. Effective Cyp51A targeting however is impeded by the multitude of viable azole-resistant mutants: as of 2015, over 140 Cyp51A azole resistant mutants have been identified [34]. In contrast, selectively preventing mFgDFV1 siRNA silencing will likely require a more extensive, and therefore less probable, set of mutations. Second, this protocol can be extended to target different regions of the $\mathrm{ABC}$ gene, different gene targets, or even different fungi-mycovirus pairs. One possible alternative to $\mathrm{FgABC} 3$ is $\mathrm{PKS} 4$, which would reduce $\mathrm{Fg}$ virulence rather than target AFR. PKS4 is implicated in zearalenone synthesis, a mycotoxin responsible for various reproductive issues [35]. Thus, inhibiting zearalenone is another option that may be desirable in certain situations, such as livestock feed.

Alternatively, one could target any essential Fg gene to directly kill Fg [36]. However, this method presents certain issues. For one, the virus' lethality suggests mFgDFV1 communicability will be hindered. Additionally, while mycoviruses are highly host specific, untargeted fungi could be affected in the event of horizontal transmission, posing a significant ecological risk [37]. Finally, this treatment could eventually be applied against other fungal plant pathogens, such as the rice blast fungi Magnaporthe oryzae, or even possibly human fungal diseases. Future studies are encouraged to explore such extensions, given a comprehensive review of ecological and biohazard risks. 
UNDERGRADUATE RESEARCH IN NATURAL AND CLINICAL SCIENCE AND TECHNOLOGY (URNCST) JOURNAL Read more URNCST Journal articles and submit your own today at: https://www.urncst.com

\section{Conclusions}

In brief, this proposal outlines the creation and validation of a mutant mycoviral system potentially capable of hindering AFR via the RISC pathway. To model this mechanism, we propose synthesizing a transgenic FgDFV1 containing a $600 \mathrm{nt}$ segment from the FgABC3 gene, an $\mathrm{ABC}$ transporter primarily responsible for tebuconazole resistance. The mycovirus will subsequently be isolated and used to infect Fg via protoplast fusion, whereby successful delivery will be confirmed via RT-PCR. Following infection, we hypothesize that $\mathrm{Fg}$ will produce siRNA complementary to the FgABC3 insert, downregulating tebuconazole resistance. To determine the validity of our hypothesis, tebuconazole efficacy, as measured by $\mathrm{MIC}_{50}$ and $\mathrm{MIC}_{90}$, will be compared to various control strains. If successful, mFgDFV1 may prove to be a useful tool in the fight against Fg AFR. As RISC is a fundamental and nearly ubiquitous aspect of fungal defense, the former gives reason to suspect that adaptation will be difficult, while the latter suggests that similar treatments can be applied against other pathogenic fungi. With the large agricultural and healthcare costs incurred by fungal infections annually, developing countermeasures against AFR is vital. Our proposal addresses this serious issue, providing a possible solution to AFR that can guide future treatment of fungal diseases in humans and crops.

\section{List of Abbreviations Used}

ABC: ATP-binding cassette

AFR: antifungal resistance

ATP: adenosine triphosphate

dsRNA: double-stranded ribonucleic acid

Fg: Fusarium graminearum

FgABC3: Fusarium graminearum ATP-binding cassette 3

FgDFV1: Fusarium graminearum deltaflexivirus 1

FHB: Fusarium head blight

mFgDFV1: modified Fusarium graminearum deltaflexivirus 1

MIC50: minimum inhibitory concentration 50

MIC90: minimum inhibitory concentration 90

mRNA: messenger ribonucleic acid

nt: nucleotide

ORF: open reading frame

PDA: potato dextrose agar

RISC: RNA induced silencing complex

RNA: ribonucleic acid

RPMI: Roswell Park Memorial Institute

RT-PCR: reverse transcription polymerase chain reaction

S. cerevisiae: Saccharomyces cerevisiae

siRNA: small interfering ribonucleic acid

UTR: untranslated region

+ssRNA: positive single-stranded ribonucleic acid

\section{Conflicts of Interest}

The authors declare that they have no conflict of interests.

Jeong et al. | URNCST Journal (2021): Volume 5, Issue 8

DOI Link: https://doi.org/10.26685/urncst.292

\section{Ethics Approval and/or Participant Consent}

No REB review was required as this paper is a proposal, not primary research.

\section{Authors' Contributions}

WDJ: made contributions to the design of the final study, drafted and revised the manuscript carefully, and gave final approval of the version to be published.

SDJ: made contributions to the design of the final study, drafted and revised the manuscript carefully, and gave final approval of the version to be published.

KW: made contributions to the design of the final study, drafted and revised the manuscript carefully, and gave final approval of the version to be published.

AL: made contributions to the design of the final study, drafted and revised the manuscript carefully, and gave final approval of the version to be published.

\section{Acknowledgments}

The authors wish to acknowledge the editor, Jeremy $\mathrm{Ng}$, for his continued technical and advisory support of this editorial.

\section{Funding}

This study was not funded.

\section{References}

[1] Fisher MC, Hawkins NJ, Sanglard D, and Gurr SJ. Worldwide emergence of resistance to antifungal drugs challenges human health and food security. Science. 2018;360(6390):739-42. https://doi.org/10.1126/science .aap7999

[2] Cowen LE, Sanglard D, Howard SJ, Rogers PD, and Perlin DS. Mechanisms of antifungal drug resistance. Cold Spring Harbor Perspectives in Medicine. 2014 Nov;5(7):a019752. https://doi.org/10.1101/cshperspect . $\mathrm{a} 019752$

[3] Hernandez H and Martinez LR. Relationship of environmental disturbances and the infectious potential of fungi. Microbiology (Reading). 2018 Mar; 164(3):233-41. https://doi.org/10.1099/mic.0.000620

[4] Roemer T and Krysan DJ. Antifungal drug development: Challenges, unmet clinical needs, and new approaches. Cold Spring Harbor Perspectives in Medicine. 2014 May;4(5):a019703. https://doi.org/ 10.1101/cshperspect.a019703

[5] Yang F, Jacobsen S, Jørgensen H, Collinge D, Svensson B, and Finnie C. Fusarium graminearum and its interactions with cereal heads: Studies in the proteomics era. Frontiers in Plant Science. 2013;4:37. https://doi.org/10.3389/fpls.2013.00037

[6] Abou Ammar G, Tryono R, D“oll K, Karlovsky P, Deising HB, and Wirsel SGR. Identification of ABC transporter genes of Fusarium graminearum with roles in azole tolerance and/or virulence. PLoS One. 2013 Nov;8(11):e79042. https://doi.org/10.1371/ journal.pone.0079042 
UNDERGRADUATE RESEARCH IN NATURAL AND CLINICAL SCIENCE AND TECHNOLOGY (URNCST) JOURNAL Read more URNCST Journal articles and submit your own today at: https://www.urncst.com

[7] Li P, Bhattacharjee P, Wang S, Zhang L, Ahmed I, and Guo L. Mycoviruses in Fusarium species: An update. Frontiers in Cellular and Infection Microbiology. 2019;9:257. https://doi.org/10.3389/fcimb.2019.00257

[8] Ghabrial SA, Suzuki N. Viruses of plant pathogenic fungi. Annual Review of Phytopathology. 2009;47:353-84. https://doi.org/10.1146/annurevphyto-080508-081932

[9] Ahlquist P, Noueiry AO, Lee WM, Kushner DB, and Dye BT. Host factors in positive strand RNA virus genome replication. Journal of Virology. 2003;77(15):8181-6. https://doi.org/10.1128/JVI.77.15 $.8181-8186.2003$

[10] Systemax.jp. PaintTool SAI [Internet]. 2021. Available from: https://www.systemax.jp/en/sai/

[11] Dang Y, Yang Q, Xue Z, Liu Y. RNA interference in fungi: Pathways, functions, and applications. Eukaryotic Cell. 2011;10(9):1148-55. https://doi.org/ 10.1128/EC.05109-11

[12] Kanehisa M and Goto S. KEGG: Kyoto encyclopedia of genes and genomes. Nucleic Acids Research. 2000 Jan;28(1):27-30. https://doi.org/10.1093/nar/28.1.27

[13] Kanehisa M. Toward understanding the origin and evolution of cellular organisms. Protein Science. 2019 Nov;28(11):1947-51. https://doi.org/10.1002/pro.3715

[14] Kanehisa M, Furumichi M, Sato Y, Ishiguro-Watanabe $\mathrm{M}$, and Tanabe $\mathrm{M}$. KEGG: Integrating viruses and cellular organisms. Nucleic Acids Research. 2020 Oct. https://doi.org/10.1093/nar/gkaa970

[15] Howe KL, Contreras-Moreira B, De Silva N, Maslen G, Akanni W, Allen J, et al. Ensembl genomes 2020Enabling non-vertebrate genomic research. Nucleic Acids Research. 2019 Oct;48(D1):D689-D695. https://doi.org/10.1093/nar/gkz890

[16] Chen X, He H, Yang X, Zeng H, Qiu D, and Guo L. The complete genome sequence of a novel Fusarium graminearum RNA virus in a new proposed family within the order Tymovirales. Archives of Virology. 2016 Oct; 161(10):2899-903. https://doi.org/10.1007/ s00705-016-2961-1

[17] ThermoFisher Scientific. Invitrogen GeneArt gene synthesis. [cited 2021 Mar 9]. Available from: https://www.thermofisher.com/ca/en/home/life-science/ cloning/gene-synthesis/geneart-gene-synthesis.html

[18] Liu Y, Zhang Y, Wang M, Cheng A, Yang Q, Wu Y, et al. Structures and functions of the 3 untranslated regions of positive-sense single-stranded RNA viruses infecting humans and animals. Frontiers in Cellular and Infection Microbiology. 2020;10:453. https://doi.org/10.3389/fcimb.2020.00453

[19] Redden H, Morse N, and Alper HS. The synthetic biology toolbox for tuning gene expression in yeast. FEMS Yeast Research. 2015 Jan;15(1):1-10. https://doi.org/10.1111/1567-1364.12188
[20] Sigmaaldrich.com [cited 2021 Mar 9]; Available from: https://www.sigmaaldrich.com/technical-documents/ protocols/biology/yeast-transformation-protocols.html

[21] Sigmaaldrich.com [cited 2021 Mar 9]; Available from: https://www.sigmaaldrich.com/life-science/ proteomics/recombinant-protein-expression/celllysis/yeast-cell-lysis.html

[22] Zhang R, Liu S, Chiba S, Kondo H, Kanematsu S, and Suzuki N. A novel single stranded RNA virus isolated from a phytopathogenic filamentous fungus, Rosellinia necatrix, with similarity to hypo-like viruses. Frontiers in Microbiology. 2014 Jul;5:360. https://doi.org/ $10.3389 /$ fmicb. 2014.00360

[23] Mahmood T and Yang PC. Western blot: Technique, theory, and troubleshooting. North American Journal of Medical Sciences. 2012 Sep;4(9):429-34. https://doi.org/10.4103/1947-2714.100998

[24] He SL and Green R. Northern blotting. Methods in Enzymology. 2013;530:75-87. https://doi.org/10.1016/ B978-0-12-420037-1.00003-8

[25] Xie J, Singh-Babak S, Cowen L. Minimum inhibitory concentration (MIC) assay for antifungal drugs. Bio-Protocol. 2012;2(20). https://doi.org/10.21769/ bioprotoc. 252

[26] Lee K-M, Cho WK, Yu J, Son M, Choi H, Min K, et al. A comparison of transcriptional patterns and mycological phenotypes following infection of Fusarium graminearum by four mycoviruses. PLoS One. 2014;9(6):e100989. https://doi.org/10.1371/journal.pone.0100989

[27] Wei S, Bian R, Andika IB, Niu E, Liu Q, Kondo H, et al. Symptomatic plant viroid infections in phytopathogenic fungi. Proceedings of the National Academy of Sciences of the United States of America. 2019;116(26):13042-50. https://doi.org/10.1073/pnas .1900762116

[28] Herkert PF, Al-Hatmi AMS, de Oliveira Salvador GL, Muro MD, Pinheiro RL, Nucci M, et al. Molecular characterization and antifungal susceptibility of clinical Fusarium species from Brazil. Frontiers in Microbiology. 2019;10:737. https://doi.org/10.3389/ fmicb.2019.00737

[29] Schwarz S, Silley P, Simjee S, Woodford N, van Duijkeren E, Johnson AP, et al. Editorial: Assessing the antimicrobial susceptibility of bacteria obtained from animals. Journal of Antimicrobial Chemotherapy. 2010;65(4):601-4. https://doi.org/10.1093/jac/dkq037

[30] Perczak A, Gwiazdowska D, Marchwińska K, Juś K, Gwiazdowski R, and Waśkiewicz A. Antifungal activity of selected essential oils against Fusarium culmorum and $F$. graminearum and their secondary metabolites in wheat seeds. Archives of Microbiology. 2019 Oct;201(8):1085-97. https://doi.org/10.1007/ s00203-019-01673-5 
UNDERGRADUATE RESEARCH IN NATURAL AND CLINICAL SCIENCE AND TECHNOLOGY (URNCST) JOURNAL Read more URNCST Journal articles and submit your own today at: https://www.urncst.com

[31] Van Dijck P, Sjollema J, Cammue BP, Lagrou K, Berman J, d'Enfert C, et al. Methodologies for in vitro and in vivo evaluation of efficacy of antifungal and antibiofilm agents and surface coatings against fungal biofilms. Microbial Cell. 2018 Jun;5(7):300-26. https://doi.org/10.15698/mic2018.07.638

[32] Lax C, Tahiri G, Patiño-Medina JA, Cánovas-Márquez JT, Pérez-Ruiz JA, Osorio-Concepción M, et al. The evolutionary significance of RNAi in the fungal kingdom. International Journal of Molecular Sciences. 2020;21(24):9348. https://doi.org/10.3390/ijms21249348

[33] Dang Y, Yang Q, Xue Z, Liu Y. RNA interference in fungi: Pathways, functions, and applications. Eukaryotic Cell. 2011;10(9):1148-55. https://doi.org/ $\underline{10.1128 / E C .05109-11}$
[34] Cowen LE, Sanglard D, Howard SJ, Rogers PD, Perlin DS. Mechanisms of antifungal drug resistance. Cold Spring Harbor Perspectives in Medicine. 2014;5(7): a019752. https://doi.org/10.1101/cshperspect.a019752

[35] Lysøe E, Klemsdal SS, Bone KR, Frandsen RJN, Johansen T, Thrane U, et al. The PKS4 gene of Fusarium graminearum is essential for zearalenone production. Applied and Environmental Microbiology. 2006;72(6):3924-32. https://doi.org/10.1128/AEM $.00963-05$

[36] Kelly AC, Ward TJ. Population genomics of Fusarium graminearum reveals signatures of divergent evolution within a major cereal pathogen. PLoS One. 2018;13(3):e0194616. https://doi.org/10.1371/journal .pone. 0194616

[37] Heo J-I, Yu J, Choi H, Kim K-H. The signatures of natural selection and molecular evolution in Fusarium graminearum virus 1. Frontiers in Microbiology. 2020; 11:600775. https://doi.org/10.3389/fmicb.2020.600775

\section{Article Information}

Managing Editor: Jeremy Y. Ng

Peer Reviewers: Sera Whitelaw, Daniel Tarade

Article Dates: Received 0603 21; Accepted 0716 21; Published Aug 2021

\section{Citation}

Please cite this article as follows:

Jeong WD, Jeong SD, Wang KR, Lo A. siRNA-mediated silencing of antifungal resistance genes: A research protocol.

URNCST Journal. 2021 Aug 20: 5(8). https://urncst.com/index.php/urncst/article/view/292

DOI Link: https://doi.org/10.26685/urncst.292

\section{Copyright}

(C) Will D. Jeong, Sean D. Jeong, Katelyn R. Wang, Alston Lo. (2021). Published first in the Undergraduate Research in Natural and Clinical Science and Technology (URNCST) Journal. This is an open access article distributed under the terms of the Creative Commons Attribution License (https://creativecommons.org/licenses/by/4.0/), which permits unrestricted use, distribution, and reproduction in any medium, provided the original work, first published in the Undergraduate Research in Natural and Clinical Science and Technology (URNCST) Journal, is properly cited. The complete bibliographic information, a link to the original publication on http://www.urncst.com, as well as this copyright and license information must be included.
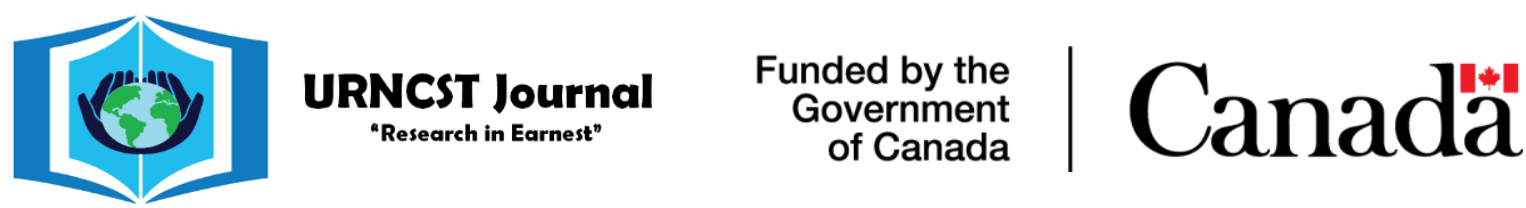

Do you research in earnest? Submit your next undergraduate research article to the URNCST Journal!

| Open Access | Peer-Reviewed | Rapid Turnaround Time | International |

| Broad and Multidisciplinary | Indexed | Innovative | Social Media Promoted |

Pre-submission inquiries? Send us an email at info@ urncst.com | Facebook, Twitter and LinkedIn: @URNCST

Submit YOUR manuscript today at https://www.urncst.com! 